\title{
Technologies and Sensor Design for the Measurement of Ground Reaction Forces in Mice: A Review
}

\author{
Tayssir Limam (D, Florian Vogl (D) and William R. Taylor*D
}

Institute of Biomechanics, ETH Zürich, 8093 Zürich, Switzerland; tayssir.limam@hest.ethz.ch (T.L.);

florian.vogl@hest.ethz.ch (F.V.)

* Correspondence: taylorb@ethz.ch

check for updates

Citation: Limam, T.; Vogl, F.; Taylor, W.R. Technologies and Sensor Design for the Measurement of Ground Reaction Forces in Mice: A Review. Biomechanics 2021, 1, 53-72. https:// doi.org/10.3390/biomechanics1010005

Received: 31 January 2021

Accepted: 20 March 2021

Published: 25 March 2021

Publisher's Note: MDPI stays neutral with regard to jurisdictional claims in published maps and institutional affiliations.

Copyright: (C) 2021 by the authors. Licensee MDPI, Basel, Switzerland. This article is an open access article distributed under the terms and conditions of the Creative Commons Attribution (CC BY) license (https:/ / creativecommons.org/licenses/by/ $4.0 /)$.

\begin{abstract}
To better understand the pathophysiology and functional outcomes of musculoskeletal and neuromotor pathologies, research is often conducted in mice models. As a key component of such research, metrics of movement, loading, symmetry, and stability all have to be assessed, ideally requiring the measurement of $3 \mathrm{D}$ ground reaction forces, which can be difficult. While the measurement of ground reaction forces (GRF) is well developed for humans, appropriate devices for mice remain rare or inadequate. Such devices need to combine high sensitivity with small dimensions, especially when the forces for each individual paw should be measured. As preparation for building such a device that can measure 3D GRF per paw in mice in an upcoming study, this systematic review of the literature identified 122 articles and 49 devices that measured the ground reaction forces for mice and other small animals. Based on a variety of criteria, such as sensitivity and resonance frequency, the miniaturisation of each device and/or its capability to measure the three components of the ground reaction forces in individual paws were judged. The devices were consequently classified; eight devices were classified as "can be adapted", nine as "hard to be adapted", and 24 as "cannot be adapted".
\end{abstract}

Keywords: functional assessment; limb loading; ground reaction forces; mice; small animals

\section{Introduction}

The measurement of the ground reaction forces (GRFs) is used in a wide range of human movement studies, for instance, to investigate the internal forces in rehabilitation [1] or sports coaching [2,3], but importantly also to monitor the progression of musculoskeletal pathologies and neuromotor disorders [4,5]. When combined with spatiotemporal and kinematics parameters, GRFs allow the loading conditions acting on internal skeletal structures to be calculated [6], muscle activity to be assessed [7], and joint contact forces to be determined [8-10].

For many research questions, direct studies in humans would be unethical, and are thus performed in animal models instead [11,12]. Consequently, researchers are increasingly interested in applying movement analysis in animal models whenever it is ethical-particularly in mice-which represent about $95 \%$ of animal models. At our institute, researchers are investigating the effects of mechanical intervention therapies for improving bone properties and musculoskeletal regeneration [13,14]; measuring the GRFs per paw in mice before and after the interventions can help better qualify the results. While GRF measurement devices for human studies are plentiful and highly developed, options for mice and other small animals remain rare and inadequate.

For the direct measurement of GRFs in humans, two main techniques are used: instrumented shoes [15,16] and force plates [17]. While instrumented shoes could be made suitable for large animals by adapting the design to the animal's paw [18], shoes are impractical for rodents, particularly because the sensor weights and sizes would impair the animal's movement. Therefore, mice studies have used commercial or custom-built force plates to measure GRFs. However, all of these force plates are generally either 
limited in the number of GRF components or are unable to measure GRFs per individual paw. Similar to the importance of measuring the three components of the GRFs per leg in humans, measuring the three components of the GRFs per paw in mice is crucial for many studies. Knowledge of the GRFs per paw in rodents is essential for assessing gait symmetry and asymmetry [19], dynamic balance [20], and local tremor [21], while the 3D GRFs are essential for determining internal loads mainly using inverse dynamics [22]. So, while measurement of just one or two GRF components or the total GRFs over all paws is sufficient for some studies, many research questions can only be answered when 3D GRFs per individual paw are available.

Unfortunately, measuring GRFs for individual mouse paws is challenging due to the small size of the animal paw, which is only $17.5 \mathrm{~mm}$ in length [23], and the small forces in the range of 0.01 to $0.2 \mathrm{~N}$ [24]. One study was able to measure left/right side forces [25] by using two force plates side by side and forcing the mouse to walk centrally, in a way that its left paws fall on the left plate and its right paws fall on the right plate. Another study covered a large force plate $(152.5 \mathrm{~mm} \times 152.5 \mathrm{~mm})$ with a walkway constructed of three separated wooden plates in which only the middle one was the same size as a mouse paw and was in direct contact with the force plate, another study was able to measure the GRFs for individual paws in mice [24]. However, such solutions remain non-optimal due to the use of large forces plates, hence restricting the assessment of multiple successive steps.

Therefore, this study reviews the force plates available for rodents and small animals and evaluates how easily they could be adapted towards a force plate design capable of measuring 3D GRFs in mice for each individual paw and successive steps.

\section{Methods}

\subsection{Literature Selection}

In this review of the literature, we investigated devices used for measuring GRFs in small animals (with an average weight of less than $1 \mathrm{~kg}$ ) during functional movements. Figure 1 presents an overview of the systematic search process and the number of publications at each step.

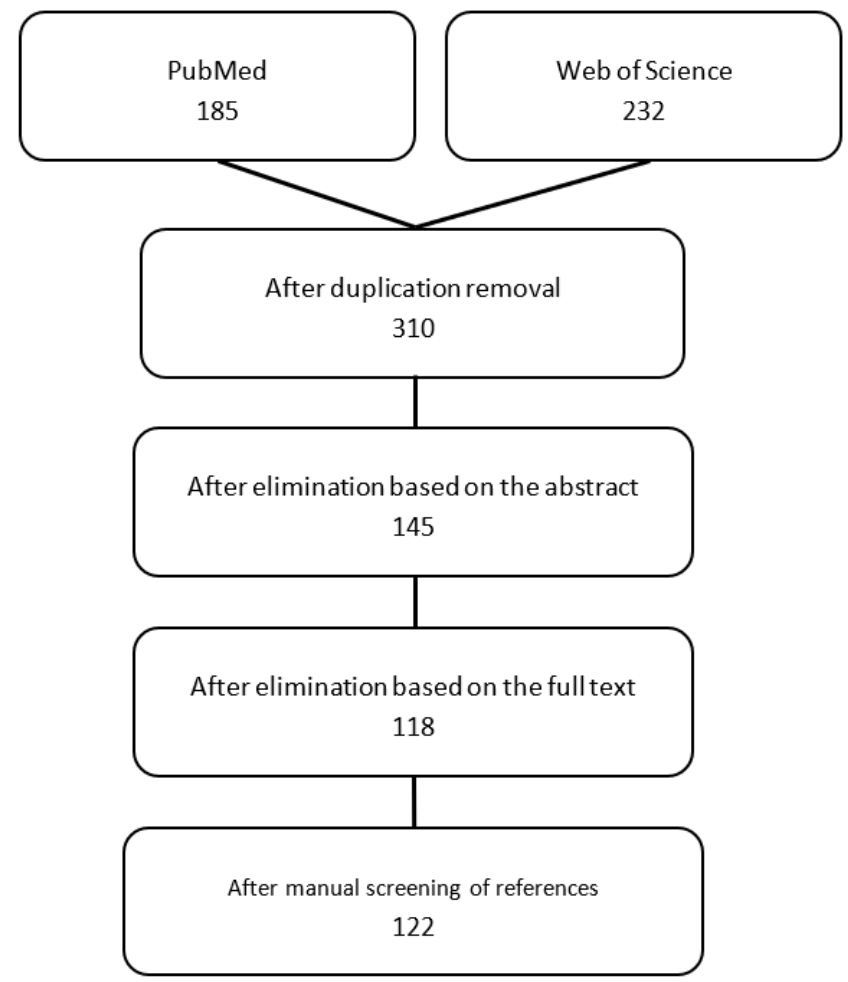

Figure 1. Articles selection steps. 
We searched two databases (Pubmed and Web of Science) while restricting the publication year to the period between 1980 and 2020 and the language to English. The exact search strings contained the terms "ground reaction forces" and "small animals" combined with an AND operator. The synonyms of small animals, such as mice, rats, rodents, ants, frogs, lizards, geckos, birds, or insects, were added using the operator OR. We excluded cats, chicks, turkeys, rabbits, and dogs (all combined with an OR) from this study using the operator NOT. The research string was the following: ((Ground reaction forces) AND ((small animals OR mice OR rats OR rodents OR ants OR frogs OR lizards OR geckos OR birds OR insects) NOT (cats OR chicks OR turkeys OR rabbits OR dogs))), with adding "ALL=" for Web of Science. This initial search in PubMed and the Web of Science returned 417 possible publications. After removing duplicates and irrelevant literature (based first on the title and abstract, then the full text), 118 remaining articles were considered relevant. An article was considered relevant when it involved a direct measurement of GRFs, the measurement device was described in the article itself, or in a cited reference and the used animals that weighed less than $1 \mathrm{~kg}$.

After manually reviewing the references cited in the remaining articles, the total number of included articles was 122.

\subsection{Criteria for Platform Classification}

We assessed the possibility of adapting the measurement technology for use in force plates to measure the three GRF components per paw in mice according to the following criteria:

- Independent measurement of 3 orthogonal components of the GRF.

- $\quad$ Determination of the centre of pressure (CoP).

- Low 'crosstalk' between the components: where an upper limit of 3\% crosstalk was considered acceptable [26].

- Sensing technique (load cells, strain gauges, gelatin slabs, water sensors ... ) and how easily the technology can be adapted for use in the assessment of mice GRFs.

- Sufficient sensitivity and resolution: the expected forces for a $20 \mathrm{~g}$ mouse are $0.01 \mathrm{~N}$ to $0.12 \mathrm{~N}$ for the vertical direction, $0.004 \mathrm{~N}$ to $0.036 \mathrm{~N}$ for the fore-aft direction, and $0.002 \mathrm{~N}$ to $0.02 \mathrm{~N}$ for the mediolateral direction [27]. Accordingly, the force plate needs to have a minimum resolution of $10 \mathrm{mN}$ in the vertical direction and $2 \mathrm{mN}$ for the horizontal directions, while for sensitivity, $10 \mathrm{~V} / \mathrm{N}$ should be sufficient.

- Linear response: According to the expected forces, the linear response should cover a range of about $0.008 \mathrm{~N}$ to $0.15 \mathrm{~N}$ for vertical forces and a range of 0.001 to $0.05 \mathrm{~N}$ for horizontal forces.

- Uniform response over the plate surface: Previous research suggests a maximum variation of 3\% for mice gait [26], even though the origin of this number was not further discussed.

- High natural frequency: If the mouse gait contains any frequencies at the natural frequency of the plate, this will lead to resonance, which causes high noise or could even damage the mechanical structure. Thus, it is important to ensure that the plate's natural frequency is well above any frequency components of the mouse movement under assessment. During mice gait, frequencies up to $30 \mathrm{~Hz}$ [28] can occur, and therefore, the natural frequency of the force plate should be at least $100 \mathrm{~Hz}$.

- $\quad$ Force plate size: A mouse hind paw about $17.5 \mathrm{~mm}$ long and about $5.8 \mathrm{~mm}$ wide [23], while the stride length is around $60 \mathrm{~mm}$, which is defined as the distance from the centre of the front paw to the centre of the ipsilateral hind paw. So, in order to measure the forces per paw, the top plate on which the animal will step cannot be smaller than $18 \mathrm{~mm}$ to fit a whole paw and not bigger than $20 \mathrm{~mm}$ to avoid overlapping paws for full-width plates (three paws per stride length). If the separate left and right plates are used in the runway, the plates can be $30 \mathrm{~mm}$ long (two paws per stride length).

We finally present the classification on how easily a device could be adapted using the following scheme: (a) if one of the previous criteria could not be met without a 
fundamental change in the sensing technique or force platform architecture, the technique was categorised as "Cannot be adapted"; (b) if the required performance criteria could potentially be achieved, but would require substantial modification and success would remain uncertain, the technique was categorised as "Hard to adapt"; (c) if the required performance could likely be achieved by straight-forward improvements, the technique was categorised as "Can be adapted"; (d) if there was missing information about four or more of the previous criteria, the device was categorised as "Insufficient information".

\section{Results and Discussion}

In this paper, we differentiate between running wheels (Table 1) and flat force plates (Tables 2-4) While the measuring principle is similar in both cases, in that the animal steps on a surface and the system measures the GRF applied to it, there are fundamental differences between walking/running on a rotating, movable surface vs. a flat fixed surface (overground movement) [29]. We furthermore categorised our results according to the GRF components the device could measure. Under each section, we present only the force plates classified as "can be adapted "and "Hard to adapt", while the devices that were classified as "cannot be adapted" or "insufficient information" are presented in the Table 4. Since the sensing technique plays an important role in classifying the devices, a small explanation of the most used force sensors in the studied devices can be found in Box 1.

In this paper, the force components were defined as follows: $F_{z}$ is the vertical component, $\mathrm{F}_{\mathrm{x}}$ is the for-aft (anteroposterior) component, and $\mathrm{F}_{\mathrm{y}}$ is the mediolateral component (Figure 2), similar to the reference [30]. The notation here may differ from some references.

Box 1. Force sensors.

Force sensors typically operate on the principle of measuring strain in a known material and then derive the applied force from this strain through the known stress-strain relationship. Strain is commonly measured using strain gauges, which come in a variety of technologies: Resistance strain gauges, for instance, consist of a metallic foil pattern on a flexible support. Because the support is flexible, applying a strain changes the geometry of the foil pattern and thus leads to a change in overall resistance. The resistance strain gauges, also called metal-foil strain gauges, are the most widespread type of strain gauges and often just called strain gauges. Semiconductor strain gauges, on the other hand, use a semiconductor material with a piezoresistive effect to measure strain. Here, it is not the geometry of a pattern that changes, but the resistance of the piezoresistive material itself changes when stress is applied. Compared to resistance strain gauges, semiconductor strain gauges offer higher measurement sensitivity but suffer from nonlinearity and temperature dependency. While resistance and semiconductor strain gauges are the most common types, there also exist other principles to measure strain. For example, in Hall effect strain sensors, a metallic strip and magnetic field are used to measure the position and thus strain. The hall effect sensors are quite robust and immune to vibration, but the accuracy of its measurement can be easily affected by external magnetic fields.

To measure forces, all types of strain sensors have to be fixed to an appropriate mechanical support structure and require the use of dedicated readout electronics such as bridge electronics or amplifiers. Load cells are an alternative to building a custom design using strain gauges. Load cells are force sensors, typically pairing resistance strain or piezoresistive strain gauges with a predefined support structure (and sometimes readout electronics), that are available as off-the-shelf components and directly measure applied force. While their performance depends on the design details, we consider load cells as a separate sensor category since their design makes them hard to adapt unless a sister device with appropriate specifications is offered by the manufacturer. 


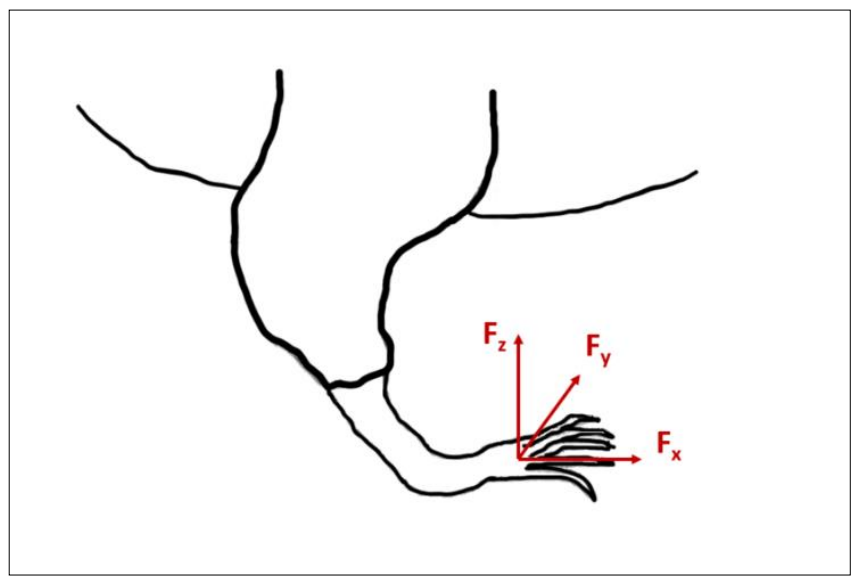

Figure 2. The ground reaction force (GRF) force components, where $F_{z}$ is the vertical component, $F_{x}$ is the for-aft (anteroposterior) component, and $\mathrm{F}_{\mathrm{y}}$ is the mediolateral component.

\subsection{Running Wheels}

A running wheel is an exercise device often used in rodent studies to investigate the effect of exercise on metabolism and obesity or to assess pain [31,32]. While most of these devices are plain, non-instrumented wheels, a few recent studies have developed running wheels that are able to measure the GRF during animal exercise (Table 1). The advantage of using running wheels for measuring GRFs is that the mouse voluntarily chooses to use the wheel [33]. This method is stress-free for the animal [33] compared to the use of flat force plates where the mouse generally has to be compelled to move by the researcher.

Table 1. The results for running wheels.

\begin{tabular}{|c|c|c|c|c|c|c|c|c|c|c|}
\hline $\begin{array}{c}\text { GRF } \\
\text { Compo- } \\
\text { nents }\end{array}$ & $\begin{array}{c}\text { Sensing } \\
\text { Tech- } \\
\text { niques }\end{array}$ & $\begin{array}{l}\text { Sensitivity/ } \\
\text { Resolution }\end{array}$ & Crosstalk & $\begin{array}{l}\text { Linearity } \\
\text { of the } \\
\text { Response }\end{array}$ & $\begin{array}{l}\text { Natural } \\
\text { Frequency }\end{array}$ & $\begin{array}{l}\text { Variation } \\
\text { across the } \\
\text { Platform }\end{array}$ & $\begin{array}{l}\text { Shape and } \\
\text { Size }\end{array}$ & Application & $\begin{array}{c}\text { Complexity } \\
\text { Level of } \\
\text { Adaptation }\end{array}$ & References \\
\hline$F_{x}$ and $F_{z}$ & $\begin{array}{l}\text { Resistance } \\
\text { strain } \\
\text { gauges }\end{array}$ & & $\begin{array}{c}\text { Vertical: } \\
1.5 \% \\
\text { Fore-aft: } \\
38 \%\end{array}$ & $\begin{array}{c}\text { Tested } \\
\text { between } \\
10 \mathrm{mN} \text { and } \\
402 \mathrm{mN}\end{array}$ & & $\begin{array}{c}\text { Strain } \\
\text { magnitude } \\
\text { varied } \\
\text { linearly } \\
\left(\mathrm{R}^{2}>0.99\right)\end{array}$ & $\begin{array}{l}\text { A standard } \\
\text { stainless- } \\
\text { steel mouse } \\
\text { running } \\
\text { wheel }\end{array}$ & Mice & $\begin{array}{l}\text { Cannot be } \\
\text { adapted }\end{array}$ & [34] \\
\hline $\begin{array}{l}\mathrm{F}_{\mathrm{x}}, \mathrm{F}_{\mathrm{y}} \\
\text { and } \mathrm{F}_{\mathrm{z}}\end{array}$ & $\begin{array}{l}\text { Hall-effect } \\
\text { sensors }\end{array}$ & & & & $\begin{array}{l}94.3 \pm \\
12.1 \mathrm{~Hz}\end{array}$ & & $\begin{array}{l}\text { Running } \\
\text { Wheel }\end{array}$ & Mice & $\begin{array}{c}\text { Hard to } \\
\text { adapt }\end{array}$ & [35] \\
\hline
\end{tabular}

Two types of running wheels have been used to measure GRFs in mice: an upright running wheel with rods based on resistance strain gauges [34] and an angled running wheel based on the Hall effect [35]. The upright wheel measured two components of the GRF per paw during mouse movement, but video records showed occasional foot-slipping or misplacement on the wheel rungs, particularly in inexperienced animals. In addition, this wheel suffered from high crosstalk (tangential forces produced $38 \%$ crosstalk in the normal force measurement) and high noise. Adding a third spring blade to measure $\mathrm{F}_{\mathrm{y}}$, would likely result in a longer vertical spring blade that could interfere with the overall size of the wheel. Since it is hard to measure all three components without an important modification of the design, in addition to the high crosstalk, the upright running wheel was classified as "Cannot be adapted". The angled running wheel measured three components of the GRF per paw and can measure GRFs of multiple paws simultaneously (contrary to the upright wheel). This design further improved on the upright running wheel by using an angled shape that reduces paw slippage and allows more natural running conditions [35]. This setup used Hall sensors instead of resistance strain gauges, which reduced the sensor noise (for more information about both technologies, please see Box 1). However, such angled running wheels were unable to determine the $\mathrm{CoP}$ and underestimated the contact times at low mouse speeds, hence resulting in less accurate stance and duty factor measurements. As the reason for this underestimation remains 
unclear, improvement may prove challenging. Furthermore, in order to measure the CoP, significant modifications, such as using a florescent pressure-sensitive material for the pads, would be required. Overall, this device was classified as "Hard to adapt".

\subsection{Flat Force Plates}

In this section, we will present the flat force plates that had enough information to be classified. The devices under the category "insufficient information" in Table 4 will not be further discussed.

\subsubsection{Devices That Can Measure Only the Vertical Component}

Many force plates used for measuring GRFs in mice can measure only the vertical component of the force (Table 4). Measuring only the vertical GRF is sufficient if only the gait patterns or the maximum magnitude of the applied forces are needed, but it is not adequate for studying internal loading conditions since this requires the three components of the GRFs. Vertical component force plates have one basic design: a large plate with sensors fixed directly under it, typically four uniaxial load cells, one under each corner of the plate. The relatively large size of load cells makes it hard to miniaturise this kind of force plate, and using only one load cell instead of four will sacrifice the measurement of the $\mathrm{CoP}$, which is essential for the majority of locomotion studies. Furthermore, to measure the three components of the GRF, the sensing technology would need to be changed.

In one study, the authors used strain gauges instead of load cells by placing one strain gauge under the corners of a mouse cage-while in this case, the miniaturisation would be easier than for load cells, the mechanical structure would need to be completely redesigned before strain gauges could be added to measure the other GRF components. Therefore, all the vertical GRF force plates were classified as "Cannot be adapted".

\subsubsection{Devices That Can Measure Two Components of the GRF}

The mediolateral component Fy of the GRF in mice is usually the smallest of the three components $(<5 \%-8 \%$ of body weight [26]. It is often neglected, and measurements are therefore presented only for the vertical and anterior-posterior forces, which explains the existence of two-component devices. However, neglecting the $\mathrm{F}_{\mathrm{y}}$ component will introduce errors in the calculation of non-sagittal joint moments using inverse dynamics approaches, especially for joints that are more distant from the paws. Thus, while sophisticated musculoskeletal models of mice have been developed to study the role of knee joint loading and its relationship to osteoarthritis, investigating the medial-lateral distribution of the loads across the knee is not possible without accurate measurement of $F_{y}[36,37]$. Furthermore, mouse musculature volume measurements show that the hip rotators are actually stronger than the hip flexors and knee flexors, indicating the significant role that non-sagittal moments could play in mouse locomotion [38].

A force plate used to assess ground reaction forces in cockroaches [39] was based on a beam design with slots in different directions, onto which semiconductor strain gauges were attached. Its simple mechanical design explains the widespread usage of this force plate. It was used in chick studies after replacing the semiconductor strain gauges with resistance strain gauges [40]. In the cockroach study, this force plate was able to measure forces with a resolution of $4 \mathrm{mN}$ [39], with low crosstalk (2\%) and a high natural frequency of $400 \mathrm{~Hz}$. The structure can be easily miniaturised, and a variation of this force plate that can measure all three GRF components already exists [26] (see the strain gauge based devices section). Therefore, this force plate was considered suitable for GRF measurement in mice and was classified as "Can be adapted".

The force plate presented by Heglund [41] was made of two perpendicular spring blades that were fixed horizontally to the plate at one end and to a base support at the other end, such that the plate was suspended. Strain gauges were attached to the spring blades structure. Such force plate designs have been used for the study of kangaroo rats [42,43]. Measuring $250 \mathrm{~mm} \times 250 \mathrm{~mm}$, this design has a high natural frequency of $180 \mathrm{~Hz}$ but 
also a high crosstalk of $16 \%$. The sensitivity and the range of linearity were not stated in the original references. Importantly, the kangaroo rats used in this study weighed $94 \mathrm{~g}$ to $125 \mathrm{~g}$, which is considerably higher than that of a mouse (approximately $20 \mathrm{~g}$ ). It is, therefore, hard to judge whether this force plate could be suitable for mice. Adding a third measurement axis to this design would be relatively easy: a vertical spring blade could be added to the structure, but this modification might decrease the natural frequency of the force plate. As a result of the uncertainty of the modifications outcome, this force plate was considered "Hard to adapt".

Using microfabricated strain sensors, an ant study [44] created a miniaturised force plate array with a high resolution of $1 \mu \mathrm{N}$ and a high natural frequency of $560 \mathrm{~Hz}$. While building a larger version of this force plate for mouse paws should be unproblematic, measurements of the lateral force Fy would require a fundamental change of the plate design. Therefore, this force plate was classified as "Hard to adapt".

In their study involving crayfish, Klarner and Barnes [45] presented a force plate that also measured two GRF components: $F_{z}$ and either $F_{x}$ or $F_{y}$, depending on the mounting orientation of the device. Based on resistance strain gauges attached to an $\mathrm{L}$ shaped beam with cavities, the plate was also sufficiently small $(14 \mathrm{~mm} \times 14 \mathrm{~mm})$ to measure single paws in mice. While the article did not specify the sensitivity and measurement range, this study measured forces of about $86 \mathrm{mN}$, which is comparable to values required for mice studies $(200 \mathrm{mN})$. Because the natural frequency remains unknown, and because simultaneous measurement of $\mathrm{F}_{\mathrm{x}}$ and $\mathrm{F}_{\mathrm{y}}$ would require drastic changes in architecture, this force plate was considered "Hard to adapt".

A study on local tremor in mice presented an opto-mechanical device that measured the two in-plane components $F_{x}$ and $F_{y}$, but not $F_{z}$ [46]. This force plate used infrared diodes and phototransistors to measure the movement of the mechanical structure in each direction, offering a high resolution of $1 \mathrm{mN}$ with a natural frequency of $100 \mathrm{~Hz}$. With a sensor size of $1.5 \mathrm{~cm}$ [21], it would appear to be suited for measuring the GRF per paw in mice. As discussed by the authors, adding a transducer to measure the vertical component would be straight-forward [46]. However, this three-component device would still be unable to measure the COP, as this would require four sensors for the vertical forces. In order to measure the CoP, more than one transducer should be added, possibly making the size of the plate excessive for GRF measurement in mice. For this reason, we considered this force plate "Hard to adapt".

Devices that use gelatine slabs were considered as "cannot be adapted" [47,48] because the slabs do not provide sufficient stability for mouse walking. Similarly, a force plate with $0.1 \mathrm{~mm}$ plate thickness used to study ants [49] is too thin to support a mouse weight, and a thicker plate would decrease the low natural frequency of $80 \mathrm{~Hz}$ leading to a risk of resonance and hence alter the measurement characteristics of this device. Therefore, this device was also classified as "cannot be adapted". The specifications of these force plates, as well as those that had insufficient information, can be found in Table 4. 
Table 2. Devices that can measure two components of the GRFs and were classified as "can adapted" or "hard to adapt".

\begin{tabular}{|c|c|c|c|c|c|c|c|c|c|c|}
\hline $\begin{array}{c}\text { GRF } \\
\text { Components }\end{array}$ & $\begin{array}{c}\text { Sensing } \\
\text { Techniques }\end{array}$ & $\begin{array}{l}\text { Sensitivity/ } \\
\text { Resolution }\end{array}$ & Crosstalk & $\begin{array}{l}\text { Linearity of the } \\
\text { Response }\end{array}$ & $\begin{array}{l}\text { Natural } \\
\text { Frequency }\end{array}$ & $\begin{array}{l}\text { Variation } \\
\text { Across the } \\
\text { Platform }\end{array}$ & Shape and Size & Application & $\begin{array}{l}\text { Complexity } \\
\text { Level of } \\
\text { Adaptation }\end{array}$ & $\begin{array}{l}\text { References and } \\
\text { Remarks }\end{array}$ \\
\hline \multirow{3}{*}{$\mathrm{F}_{\mathrm{z}}$ and $\mathrm{F}_{\mathrm{x}}$} & $\begin{array}{l}\text { Semiconductor } \\
\text { strain gauges }\end{array}$ & $\begin{array}{l}\text { Resolution } \\
0.5 \mathrm{mN}\end{array}$ & $<2 \%$ & $\begin{array}{l}\text { In the range } \\
0.001-0.1 \mathrm{~N}\end{array}$ & $400-650 \mathrm{~Hz}$ & Less than $7 \%$ & $\begin{array}{l}107 \mathrm{~mm} \times \\
60 \mathrm{~mm}\end{array}$ & Cockroach & Can be adapted & {$[39,50,51]$} \\
\hline & $\begin{array}{c}\text { MEMS } \\
\text { Piezoresistive } \\
\text { strain gauges }\end{array}$ & Resolution $1 \mu \mathrm{N}$ & & & $560 \mathrm{~Hz}$ & & $\begin{array}{l}2 \mathrm{~mm} \times \\
0.98 \mathrm{~mm}\end{array}$ & Ants & Hard to adapt & [44] \\
\hline & $\begin{array}{l}\text { Resistance strain } \\
\text { gauges }\end{array}$ & & $<2 \%$ & & $\begin{array}{c}180 \mathrm{~Hz} \text { (the } \\
\text { large plates) } \\
300 \mathrm{~Hz} \text { (the } \\
\text { lighter plates) }\end{array}$ & $2 \%$ & $\begin{array}{l}\text { Runway each } \\
\text { plate } 250 \mathrm{~mm} \times \\
250 \mathrm{~mm}\end{array}$ & Kangaroo rats & Hard to adapt & [41-43] \\
\hline $\mathrm{F}_{\mathrm{x}}$ and $\mathrm{F}_{\mathrm{y}}$ & $\begin{array}{l}\text { IR-emitting diode } \\
\text { and a } \\
\text { phototransistor }\end{array}$ & $\begin{array}{l}\text { Resolution } \\
1 \mathrm{mN}\end{array}$ & & $\begin{array}{l}\text { Linear in the } \\
\text { range of } \\
\pm 100 \mu \mathrm{m}\end{array}$ & $100 \mathrm{~Hz}$ & & $\begin{array}{l}150 \mathrm{~mm} \text { in } \\
\text { diameter }\end{array}$ & Mice & Hard to adapt & {$[21,28,46,52]$} \\
\hline$F_{z}$ and $\left(F_{x}\right.$ or $\left.F_{y}\right)$ & $\begin{array}{l}\text { Resistance strain } \\
\text { gauges }\end{array}$ & & $5 \%$ & & & $11 \%$ & Area $220 \mathrm{~mm}^{2}$ & Crayfish & Hard to adapt & [45] \\
\hline
\end{tabular}




\subsubsection{Devices That Can Measure Three Components of the GRF}

\section{- $\quad$ Load-cell based devices}

The most common force plates in human kinesiology are based on three-axis load cells fixed underneath a plate (Table 4). Devices in this category include commercial products (e.g., by Kistler, AMTI, etc.) but also custom-built force plates [53,54]. These devices exist in many variations and can measure all three GRF components, have high sensitivity, low cross talk, and a high natural frequency. Due to their large size (the smallest force plate in this group measures approximately $150 \mathrm{~mm} \times 150 \mathrm{~mm}$ ), they are only suited for full body GRF measurement over multiple steps. However, no force plate is yet small enough to measure individual steps in mice, which is required when studying the mechanics of individual limbs. Here, the limiting factor for miniaturisation is the relatively large size of the load cell; the smallest sensors available on the market have a diameter of circa $17 \mathrm{~mm}$. Therefore, the force plate cannot easily be shrunk to measure individual mouse paws and reducing the number of loading cells to make the force plate smaller would entail giving up the capability to determine the COP. Consequently, we classified these devices as "Cannot be adapted".

- $\quad$ Resistance and semiconductor strain gauge based devices

In contrast to load cells, resistance strain gauges (metallic) and semiconductor strain gauges (piezoresistive) typically have flexible support, which can be mounted on almost any kind of flat surface. They are small, with dimensions in the millimetre-range. Their flexibility and small size allow a variety of 3D sensor designs for small applications. More information on these technologies can be found in Box 1.

Strain gauge technologies have been implemented in force plates to study rats $[27,55]$, chicks [40,56], geckos [57], as well as in cockroaches [39], albeit as an adaptation of the twocomponent force plate discussed above. While the gecko force plate used semiconductor strain gauges and reached a range of measurement of $0.001-0.1 \mathrm{~N}$, the chick [56] and rat [27] force plates used metal strain gauges to reach $0.1-4 \mathrm{~N}$. The natural frequency was high in all the force plate variations $(\geq 240 \mathrm{~Hz}$ ), with reported crosstalk values below $5 \%$. The design of the force plate can be miniaturised, and by replacing the strain gauges with a model more suitable for the mice measurement range (e.g., a model with higher resistance), this force plate could be adapted to measure the GRF per paw in mice. Such a modification of the resistance strain gauge model was successfully undertaken to measure force in vampire bats [58]. This device had a natural frequency of $128 \mathrm{~Hz}$, which remains sufficiently high for mice studies. Furthermore, as vampire bats (30 g) have comparable weights to mice (20 to $25 \mathrm{~g}$ ), the force plate sensitivity and measurement range should be sufficient for one paw mice studies. We thus classify this group of force plates as "Can be adapted".

In a study on locusts [59], a design similar to that used for cockroach studies was used, but instead of having four connected beams (each with three semiconductor strain gauges), it used only one perpendicular beams structure with six semiconductor strain gauges: two for each direction. The authors reported a sensitivity of $12.60 \mathrm{~V} / \mathrm{N}$, a natural frequency of $527 \mathrm{~Hz}$ and a crosstalk of $3 \%$. The measurements of $150 \mathrm{~mm} \times 75 \mathrm{~mm}$ suggest that this solution could also be reduced to measure mouse paws. Moreover, the use of four of these sensors under a single plate would allow the measurement of COP. Therefore, this force plate was classified as "Can be adapted".

A force plate that was used to capture GRFs in lizards [60] and frogs [61] was based on resistance strain gauges on a T-shaped beam structure under a $30 \mathrm{~mm} \times 30 \mathrm{~mm}$ plate. This beam structure was either used in a vertical orientation to measure climbing animals [60,62] or in a horizontal orientation for studies on frog jumps or gecko gait $[63,64]$. The device has a sufficiently high natural frequency of $277 \mathrm{~Hz}$ and a resolution of about $2 \mathrm{mN}$. The reported crosstalk $(<5 \%)$, while in an acceptable range, would require improvement. This kind of mechanical structure could indeed be suitable for mouse GRF measurements, and by decreasing the load carrier size, this device could be used to measure GRFs in mice per paw. Therefore, this force plate was considered "Can be adapted". 
Semiconductor strain gauges have also been attached to a perpendicular beams structure to assess GRFs in ants [30], which have an average weight of $20 \mathrm{mg}$ [65]. With a plate size of $4 \mathrm{~mm} \times 4 \mathrm{~mm}$, a resolution up to $1 \mu \mathrm{N}$, and a natural frequency of $280 \mathrm{~Hz}$, this platform could be suitable for mice. However, due to the big weight and size difference between ants and mice, some modification would be needed (e.g., the size of the plate needs to be bigger to fit the mouse paw size), and more tests would be required to ensure the stability and rigidity of this force plate when a mice moves over it. We tentatively classify this force plate as "Can be adapted".

Another force plate based on semiconductor strain gauges was used in stick insects studies [66,67]. It had a plate size of $5 \mathrm{~mm} \times 5 \mathrm{~mm}$ and used a perpendicular blade structure that host the semiconductor strain gauges. This device had a resolution of $0.05 \mathrm{mN}$, which would be well suitable for mice measurements. However, since the stability and rigidity of the plate when used with mice remains unclear and the natural frequency was unreported, we classify this device as "Hard to adapt".

A modification of a two components force plate described above [41] allowed the measurement of the three components and was used in lizard studies $[68,69]$. Based on resistance strain gauges attached to a spring blade structure, the force plate had a resolution of $15 \mathrm{mN}$. While the size of the plate was $200 \mathrm{~mm} \times 600 \mathrm{~mm}$, which is too big to measure GRFs in mice per paw, miniaturisation of this force plate should be possible based on the mechanical structure and the sensing technique. However, the natural frequency was not reported for this design, and it is hard to foresee how the required modification and miniaturisation would affect the device characteristics. Therefore, this force plate, similar to the previous one, was classified as "Hard to adapt".

Another force plate in the strain gauge category is the octagonal rings force plate. Two versions of this force plate were used to study lizards and birds, respectively [70]. The difference between the two versions was mainly the size of the components, based on the size of the animal under investigation. The force plates contained four flexible octagonal rings, on which the resistance strain gauges were attached; these rings were then mounted under the four corners of the force plate. The version for lizards reported a higher resolution: $0.026 \mathrm{~N}$ in the $\mathrm{Z}, 0.062 \mathrm{~N}$ in the $\mathrm{X}$, and $0.095 \mathrm{~N}$ in the $\mathrm{Y}$ direction, but these values are insufficient for mice studies, especially for the horizontal directions. Additionally, no information about the natural frequency was given. In order to adapt this force plate, some modifications would be needed in order to improve the sensitivity (changing the material or the thickness of the structure), and further testing would be required in order to ensure that the natural frequency is sufficiently high. Due to the needed modification and the lack of information about the natural frequency, we classified this device as "Hard to adapt". 
Table 3. Devices that can measure three components of the GRFs and were classified as "can adapted" or "hard to adapt".

\begin{tabular}{|c|c|c|c|c|c|c|c|c|c|c|}
\hline GRF Components & Sensing Techniques & Sensitivity/Resolution & Crosstalk & $\begin{array}{l}\text { Linearity of the } \\
\text { Response }\end{array}$ & $\begin{array}{c}\text { Natural } \\
\text { Frequency }\end{array}$ & $\begin{array}{l}\text { Variation } \\
\text { Across the } \\
\text { Platform }\end{array}$ & Shape and Size & Application & $\begin{array}{l}\text { Complexity } \\
\text { Level of } \\
\text { Adaptation }\end{array}$ & $\begin{array}{c}\text { References } \\
\text { and Remarks }\end{array}$ \\
\hline \multirow{13}{*}{$\mathrm{F}_{\mathrm{v}}, \mathrm{F}_{\mathrm{x}}$, and $\mathrm{Fy}$} & $\begin{array}{l}\text { Resistance strain } \\
\text { gauges }\end{array}$ & $\begin{array}{c}8.5 \mathrm{~V} / \mathrm{N} \text { in the } \mathrm{Z} \\
\text { direction and } 5.0 \mathrm{~V} / \mathrm{N} \text { in } \\
\text { the } \mathrm{Y} \text { and } \mathrm{X} \text { directions }\end{array}$ & $\begin{array}{l}\text { Between vertical } \\
\text { and lateral } 2 \%\end{array}$ & $\begin{array}{l}\text { In the range of } \\
0.1 \text { to } 4 \mathrm{~N}\end{array}$ & & & $105 \mathrm{~mm} \times 105 \mathrm{~mm}$ & Rats & Can be adapted & $\begin{array}{c}{[26,27,55,71-81]} \\
\text { Was also used } \\
\text { in runways }\end{array}$ \\
\hline & $\begin{array}{l}\text { Resistance strain } \\
\text { gauges }\end{array}$ & Resolution $500 \mathrm{mN}$ & $<5 \%$ & $\begin{array}{l}\text { In the range of } \\
0.1 \text { to } 4 \mathrm{~N}\end{array}$ & $240 \mathrm{~Hz}$ & $<7 \%$ & $100 \mathrm{~mm} \times 80 \mathrm{~mm}$ & Chicks & Can be adapted & {$[26,40,56]$} \\
\hline & $\begin{array}{l}\text { Resistance strain } \\
\text { gauges }\end{array}$ & & $\begin{array}{l}16 \% \text { between } \\
\text { horizontal } \\
\text { directions }\end{array}$ & & $\geq 128 \mathrm{~Hz}$ & & $\begin{array}{l}74.6 \mathrm{~mm} \times \\
155 \mathrm{~mm}\end{array}$ & Vampire bats & Can be adapted & {$[58,82]$} \\
\hline & $\begin{array}{l}\text { Resistance strain } \\
\text { gauges }\end{array}$ & $\begin{array}{l}\text { Resolution } 2 \mathrm{mN} \text { in the } \\
\mathrm{X} \text { and } \mathrm{Y} \text { directions and } \\
3 \mathrm{mN} \text { in the } Z \text { direction }\end{array}$ & $<5 \%$ & & $277 \mathrm{~Hz}$ & & $30 \mathrm{~mm} \times 30 \mathrm{~mm}$ & $\begin{array}{l}\text { Lizard } \\
\text { Frog }\end{array}$ & Can be adapted & {$[60-64,83-85]$} \\
\hline & $\begin{array}{l}\text { Semiconductor strain } \\
\text { gauges }\end{array}$ & & $<5 \%$ & $\begin{array}{l}\text { In the range of } \\
0.0001-0.1 \mathrm{~N}\end{array}$ & $400 \mathrm{~Hz}$ & & $110 \mathrm{~mm} \times 60 \mathrm{~mm}$ & Gecko & Can be adapted & [57] \\
\hline & $\begin{array}{l}\text { Semiconductor strain } \\
\text { gauges }\end{array}$ & $\begin{array}{c}\text { Resolution } \mathrm{Fx}=5.4 \mu \mathrm{N}, \\
\mathrm{F}_{\mathrm{y}}=2.9 \mu \mathrm{N} \text { and } \\
\mathrm{F}_{\mathrm{v}}=10.8 \mu \mathrm{N}\end{array}$ & $4 \%-6 \%$ & & $201 \mathrm{~Hz}$ & & $4 \mathrm{~mm} \times 4 \mathrm{~mm}$ & Ants & Can be adapted & {$[30,65,86,87]$} \\
\hline & $\begin{array}{c}\text { Semiconductor stain } \\
\text { gauges }\end{array}$ & Sensitivity $12.60 \mathrm{~V} / \mathrm{N}$ & $3 \%$ & & $527 \mathrm{~Hz}$ & & $15 \mathrm{~mm} \times 7.5 \mathrm{~mm}$ & Locust & Can be adapted & {$[59,88]$} \\
\hline & $\begin{array}{l}\text { Resistance strain } \\
\text { gauges }\end{array}$ & Resolution $15 \mathrm{mN}$ & & & & & $200 \mathrm{~mm} \times 600 \mathrm{~mm}$ & Lizard & Hard to adapt & {$[68,69]$} \\
\hline & \multirow[t]{2}{*}{$\begin{array}{l}\text { Resistance } \\
\text { strain-gauges }\end{array}$} & $\begin{array}{l}\text { Resolution } 0.026 \mathrm{~N} \text {, in } \\
\text { the } \mathrm{Z} \text { direction, } 0.062 \mathrm{~N} \\
\text { in the } \mathrm{X} \text { direction, and } \\
0.095 \mathrm{~N} \text { in the } \mathrm{Y} \\
\text { direction }\end{array}$ & $\begin{array}{l}3.2 \% \text { of vertical in } \\
\text { the } X \text { direction } \\
\text { and } 4.4 \% \text { of the } \\
\text { vertical force in } \\
\text { the } Y \text { direction }\end{array}$ & & & & & Lizard & Hard to adapt & \multirow{2}{*}{$\begin{array}{c}{[70]} \\
\text { Supplementary } \\
\text { information of [70] }\end{array}$} \\
\hline & & $\begin{array}{l}\text { Resolution } 0.05 \mathrm{~N} \text { in the } \\
Z \text { direction, } 0.03 \mathrm{~N} \text { in } \\
\text { the } \mathrm{X} \text { direction, and } \\
0.02 \mathrm{~N} \text { in the } \mathrm{Y} \text { direction }\end{array}$ & $\begin{array}{l}\text { Vertical force was } \\
3.2 \% \text { in the } \mathrm{X} \\
\text { direction and } 4.4 \% \\
\text { in the Y direction }\end{array}$ & & & & & Bird & Hard to adapt & \\
\hline & $\begin{array}{c}\text { Semiconductor strain } \\
\text { gauges }\end{array}$ & Resolution $0.05 \mathrm{mN}$ & & & & & $5 \mathrm{~mm} \times 5 \mathrm{~mm}$ & Stick insect & Hard to adapt & {$[66,67,89,90]$} \\
\hline & $\begin{array}{c}\text { Semiconductor strain } \\
\text { gauges for X and Y } \\
\text { directions + Water } \\
\text { pressure sensors for } \\
\text { the Z-direction }\end{array}$ & & & $\begin{array}{l}\text { In the range } \\
0-3 \mathrm{mN} \text { for the } \mathrm{X} \\
\text { and } \mathrm{Y} \text { directions } \\
\text { and in the range } \\
0-5 \mathrm{mN} \text { for the } \\
\mathrm{Z} \text { direction }\end{array}$ & & & & $\begin{array}{l}\text { Stick insect and } \\
\text { cockroaches }\end{array}$ & Hard to adapt & [91] \\
\hline & $\begin{array}{l}\text { MEMS piezoresistive } \\
\text { strain gauges }\end{array}$ & $\begin{array}{l}\text { Sensitivity of } 55 \mathrm{~V} / \mathrm{N} \text { in } \\
\text { the vertical direction } \\
\text { and } 12 \mathrm{~V} / \mathrm{N} \text { in } \\
\text { horizontal directions }\end{array}$ & & $\begin{array}{l}\text { Linear in the in } \\
\text { range of } 1-100 \mathrm{mN}\end{array}$ & $900 \mathrm{~Hz}$ & & $\begin{array}{l}5.3 \mathrm{~mm} \text { square } \\
\text { plate }\end{array}$ & Cockroach & Hard to adapt & [92] \\
\hline
\end{tabular}


Table 4. Devices in the "cannot be adapted" and "insufficient information" catagories.

\begin{tabular}{|c|c|c|c|c|c|c|c|c|c|c|}
\hline $\begin{array}{l}\text { GRF } \\
\text { Components }\end{array}$ & Sensing Techniques & Sensitivity/ Resolution & Crosstalk & $\begin{array}{l}\text { Linearity of the } \\
\text { Response }\end{array}$ & $\begin{array}{l}\text { Natural } \\
\text { Frequency }\end{array}$ & $\begin{array}{l}\text { Variation } \\
\text { Across the } \\
\text { Platform }\end{array}$ & Shape and Size & Application & $\begin{array}{l}\text { Complexity Level } \\
\text { of Adaptation }\end{array}$ & $\begin{array}{l}\text { References and } \\
\text { Remarks }\end{array}$ \\
\hline \multirow{7}{*}{$\mathrm{Fz}$} & Uniaxial load cell & Resolution $0.02 \mathrm{~N}$ & & $\begin{array}{l}\text { Range of measurement } \\
0-2.5 \mathrm{~N}\end{array}$ & & & \multirow{7}{*}{$\begin{array}{l}\text { Force plate } 300 \mathrm{~mm} \times \\
300 \mathrm{~mm} \\
\text { Force plate } 460 \mathrm{~mm} \times \\
510 \mathrm{~mm} \\
\text { Force plate } 177.8 \mathrm{~mm} \times \\
177.8 \mathrm{~mm} \\
\text { Runway of } 1000 \\
\text { mm-1200 mm length } \\
\text { and adjustable width } \\
\text { Runway of } 420 \mathrm{~mm} \text { with } \\
\text { four force plate of } \\
38 \mathrm{~mm} \times 30 \mathrm{~mm} \text { each } \\
\text { Elevated force plates } \\
40 \mathrm{~mm} \times 40 \mathrm{~mm} \text { each } \\
\text { Glass plate under the } \\
\text { mouse cage }\end{array}$} & Mice & $\begin{array}{l}\text { Cannot be } \\
\text { adapted }\end{array}$ & [93-96] \\
\hline & Uniaxial load cell & $\begin{array}{l}\text { Sensitivity: } 112, \\
410 \mathrm{mV} / \mathrm{kN}\end{array}$ & & & & & & Rats & $\begin{array}{l}\text { Cannot be } \\
\text { adapted }\end{array}$ & [97] \\
\hline & uniaxial load cells & & & & & & & $\begin{array}{l}\text { Mice } \\
\text { Rats }\end{array}$ & $\begin{array}{l}\text { Cannot be } \\
\text { adapted }\end{array}$ & {$[98,99]$} \\
\hline & Uniaxial lBased iload cell & & & $\begin{array}{l}\text { Linear between } \\
0-1.94 \mathrm{~N}\end{array}$ & & & & & $\begin{array}{l}\text { Cannot be } \\
\text { adapted }\end{array}$ & [100-104] \\
\hline & Strain gauges load cell & & & & & & & Mice & $\begin{array}{l}\text { Cannot be } \\
\text { adapted }\end{array}$ & [105] \\
\hline & $\begin{array}{l}\text { load cells 5-OMEGA, } \\
\text { model LCL-227G }\end{array}$ & & & & & & & Rats & $\begin{array}{l}\text { Cannot be } \\
\text { adapted }\end{array}$ & [106] \\
\hline & Resistance strain gauges & & $<2 \%$ & linearity $99 \%$ & & & & Mice & $\begin{array}{l}\text { Cannot be } \\
\text { adapted }\end{array}$ & [107] \\
\hline \multirow{4}{*}{$F_{z}$ and $F_{x}$} & $\begin{array}{l}\text { Semiconductor strain } \\
\text { gauges }\end{array}$ & & & & \multirow[t]{4}{*}{$80 \mathrm{~Hz}$} & & $5 \mathrm{~mm} \times 5 \mathrm{~mm}$ & Ants & $\begin{array}{l}\text { Cannot be } \\
\text { adapted }\end{array}$ & [49] \\
\hline & $\begin{array}{l}\text { Gelatin slab (Photoelastic } \\
\text { material) between } \\
\text { polarizing filter and a light } \\
\text { source) }\end{array}$ & & & & & & $\begin{array}{l}102 \mathrm{~mm} \times 305 \mathrm{~mm} \\
286 \mathrm{~mm} \times 286 \mathrm{~mm} \\
245 \mathrm{~mm} \times 245 \mathrm{~mm}\end{array}$ & Cockroaches & $\begin{array}{l}\text { Cannot be } \\
\text { adapted }\end{array}$ & {$[47,48]$} \\
\hline & Uniaxial force sensors & & & & & & & Beetles & $\begin{array}{l}\text { Insufficient } \\
\text { information }\end{array}$ & [108] \\
\hline & Strain gauges & & & & & & & Caterpillars & $\begin{array}{l}\text { Insufficient } \\
\text { information }\end{array}$ & {$[109,110]$} \\
\hline \multirow{5}{*}{$\mathrm{F}_{\mathrm{v}}, \mathrm{Fx}$ and $\mathrm{F}_{\mathrm{z}}$} & $\begin{array}{l}\text { Load cell } \\
\text { (Kistler platform 9286A) }\end{array}$ & Resolution $\mathrm{Fz}<250 \mathrm{mN}$ & $\begin{array}{l}<0.05 \% \text { between } \\
\text { vertical and } \\
\text { lateral }\end{array}$ & $\begin{array}{l}\text { Linearity of } 0.5 \% \text { for a } \\
\text { range of }-2.5 \mathrm{kN} \text { to } \\
2.5 \mathrm{kN} \mathrm{for} \mathrm{lateral} \\
\text { direction and a range } \\
\text { of } 0 \text { to } 10 \mathrm{kN} \text { for the } \\
\text { vertical direction }\end{array}$ & \multirow[t]{5}{*}{$200 \mathrm{~Hz}$} & & $400 \mathrm{~mm} \times 600 \mathrm{~mm}$ & Rats & $\begin{array}{l}\text { Cannot be } \\
\text { adapted }\end{array}$ & $\begin{array}{l}\text { [112] data sheet } \\
\text { of Kistler 9286A }\end{array}$ \\
\hline & Load cell & Sensitivity $2 \mathrm{mV} / \mathrm{V}$ & \multirow{4}{*}{$\begin{array}{l}1 \% \text { between } \\
\text { vertical and } \\
\text { lateral }\end{array}$} & \multirow{4}{*}{$\begin{array}{l}\text { Range of measurement } \\
0-2500 \mathrm{~N}\end{array}$} & & & $\begin{array}{l}\text { Runway with four } \\
\text { force plate }\end{array}$ & Rats & $\begin{array}{l}\text { Cannot be } \\
\text { adapted }\end{array}$ & [113] \\
\hline & $\begin{array}{l}\text { Load cell } \\
\text { (kistler, type 9251A) }\end{array}$ & Resolution $0.01 \mathrm{~N}$ & & & & & $\begin{array}{l}\text { Runway } 1200 \mathrm{~mm} \times \\
88 \mathrm{~mm}\end{array}$ & Rats & $\begin{array}{l}\text { Cannot be } \\
\text { adapted }\end{array}$ & $\begin{array}{l}{[114,115]} \\
\text { Datasheet }\end{array}$ \\
\hline & Load cells & & & & & & $\begin{array}{l}\text { Runway of } 760 \mathrm{~mm} \times \\
80 \mathrm{~mm}\end{array}$ & Rats & $\begin{array}{l}\text { Cannot be } \\
\text { adapted }\end{array}$ & {$[11,25,116,117]$} \\
\hline & Load cell FT3/10 ATI & Resolution $0.01 \mathrm{~N}$ & & & & & $\begin{array}{l}\text { Runway of four } \\
\text { separated force plates }\end{array}$ & Rats & $\begin{array}{l}\text { Cannot be } \\
\text { adapted }\end{array}$ & [118-121] \\
\hline
\end{tabular}


Table 4. Cont

\begin{tabular}{|c|c|c|c|c|c|c|c|c|c|c|}
\hline $\begin{array}{l}\text { GRF } \\
\text { Components }\end{array}$ & Sensing Techniques & Sensitivity/ Resolution & Crosstalk & $\begin{array}{l}\text { Linearity of the } \\
\text { Response }\end{array}$ & $\begin{array}{l}\text { Natural } \\
\text { Frequency }\end{array}$ & $\begin{array}{l}\text { Variation } \\
\text { Across the } \\
\text { Platform }\end{array}$ & Shape and Size & Application & $\begin{array}{l}\text { Complexity Level } \\
\text { of Adaptation }\end{array}$ & $\begin{array}{l}\text { References and } \\
\text { Remarks }\end{array}$ \\
\hline & $\begin{array}{l}\text { Load cell FSG15N1A } \\
\text { Honeywell }\end{array}$ & Sensitivity $0.24 \mathrm{~V} / \mathrm{N}$ & & $\begin{array}{l}\text { The measuring range } \\
\text { of } 0-1500 \mathrm{~g}\end{array}$ & & & $\begin{array}{l}\text { Sensor array in a } \\
\text { runway of } 125 \mathrm{~mm} \times \\
75 \mathrm{~mm}\end{array}$ & Rats & $\begin{array}{l}\text { Cannot be } \\
\text { adapted }\end{array}$ & [122] Datasheet \\
\hline & Load cell (nano 17, ATI) & Resolution $1 / 160 \mathrm{~N}$ & & & & & $70 \mathrm{~mm} \times 150 \mathrm{~mm}$ & Rats & $\begin{array}{l}\text { Cannot be } \\
\text { adapted }\end{array}$ & $\begin{array}{l}{[124]} \\
\text { Sensor } \\
\text { Specification }\end{array}$ \\
\hline & Load cell (ATI nano17) & Resolution $300 \mathrm{mN}$ & & & $200 \mathrm{~Hz}$ & & $80 \mathrm{~mm} \times 9 \mathrm{~mm}$ & $\begin{array}{l}\text { Small Birds/ } \\
\text { Lizard/Frogs }\end{array}$ & $\begin{array}{l}\text { Cannot be } \\
\text { adapted }\end{array}$ & {$[125-130]$} \\
\hline & $\begin{array}{l}\text { Load cell kistler force } \\
\text { plates }\end{array}$ & threshold Fz $<250 \mathrm{mN}$ & $<2 \%$ & $\begin{array}{l}\text { In the range of } 2.5 \text { to } \\
2.5 \mathrm{kN} \text { in } X \text { and } Y \text { and } \\
0 \text { to } 10 \mathrm{kN} \text { in } Z\end{array}$ & $200 \mathrm{~Hz}$ & & $400 \mathrm{~mm} \times 600 \mathrm{~mm}$ & Birds & $\begin{array}{l}\text { Cannot be } \\
\text { adapted }\end{array}$ & $\begin{array}{l}{[132] \text { + data sheet }} \\
\text { of Kistler 9286A }\end{array}$ \\
\hline & $\begin{array}{l}\text { Load cell } \\
\text { kistler force plates }\end{array}$ & Resolution $\pm 0.01 \mathrm{~N}$ & & & $200 \mathrm{~Hz}$ & & $200 \mathrm{~mm} \times 100 \mathrm{~mm}$ & Birds & $\begin{array}{l}\text { Cannot be } \\
\text { adapted }\end{array}$ & [53] \\
\hline & $\begin{array}{l}\text { Load cell } \\
\text { Bertec force plate }\end{array}$ & $\begin{array}{l}\text { Sensitivities } 5 \mathrm{mN} \text { for } \\
\text { horizontal and } 10 \mathrm{mN} \\
\text { for vertical force } \\
\text { components }\end{array}$ & & $\begin{array}{l}\text { The measurement } \\
\text { range }-10 \text { to } 10 \mathrm{kN}\end{array}$ & $800 \mathrm{~Hz}$ & & $\begin{array}{l}400 \mathrm{~mm} \times 600 \mathrm{~mm} \\
150 \mathrm{~mm} \times 150 \mathrm{~mm}\end{array}$ & Birds & $\begin{array}{l}\text { Cannot be } \\
\text { adapted }\end{array}$ & $\begin{array}{l}{[133-135]} \\
{[53,136]}\end{array}$ \\
\hline & $\begin{array}{l}\text { Hall Effect } \\
\text { (HE6X6 by AMTI) }\end{array}$ & $\begin{array}{l}\text { Resolution } \\
2.5 \mathrm{mN}\end{array}$ & $\begin{array}{l}1 \% \text { in the } X \text { and } \\
Y \text { and } 2 \% \text { in the } \\
Z \text { direction }\end{array}$ & & $38 \mathrm{~Hz}$ & & $\begin{array}{l}152 \mathrm{~mm} \times 152 \mathrm{~mm} \\
105 \mathrm{~mm} \times 110 \mathrm{~mm}\end{array}$ & $\begin{array}{l}\text { Rats } \\
\text { Mice }\end{array}$ & $\begin{array}{l}\text { Cannot be } \\
\text { adapted }\end{array}$ & {$[24,137-147]$} \\
\hline & Strain gauges & & & & & & $600 \mathrm{~mm} \times 200 \mathrm{~mm}$ & Lizards & $\begin{array}{l}\text { Insufficient } \\
\text { information }\end{array}$ & [69] \\
\hline & Strain gauges & & & & & & $\begin{array}{l}\text { cylindrical sensitive } \\
\text { region of } 38 \mathrm{~mm}\end{array}$ & Opossums & $\begin{array}{l}\text { Insufficient } \\
\text { information }\end{array}$ & {$[149,150]$} \\
\hline & Not mentioned & Resolution $1 \mathrm{mN}$ & & & & & & Locust & $\begin{array}{l}\text { Insufficient } \\
\text { information }\end{array}$ & [151] \\
\hline
\end{tabular}




\section{Synopsis}

In this paper, we have reviewed the technologies and devices that were used to assess GRFs in rodents and small animals in order to find a device that could be adapted for measuring the three components of the GRF for individual steps in mouse gait. From 49 studied devices, we classified eight as "Can be adapted", nine as "Hard to adapt", 24 as "Cannot be adapted", and the rest were classified as "Insufficient information".

The main decisive factors for the classifications turned out to be miniaturisation and sensitivity, which are both highly linked to the underlying sensing technique. Load cells are generally bulky and have a minimal size that is too large to measure individual mouse paws for consecutive steps. Consequently, all eight of the devices categorised as "Can be adapted" were based on strain gauges. Four of those devices were based on resistance strain gauges $[27,56,58,60]$, and four devices on semiconductor strain gauges $[30,39,57,59]$. Both types are available in small sizes of a few millimetres, and thus, force plates using strain gauges can often be simply scaled down. While semiconductor strain gauges have about fifty times higher gauge factors than resistance strain gauges, they suffer from a higher sensitivity to temperature variations, a higher temperature drift, and a non-linear resistance-strain relation. For these reasons, it is preferable to use metal strain gauges, as long as their sensitivity is sufficient. For the vertical forces arising in mouse gait (between $0.01 \mathrm{~N}$ and $0.2 \mathrm{~N}$ ), the sensitivity of metal strain gauges is sufficient, while the situation is less clear for the smaller horizontal forces (between $0.002 \mathrm{~N}$ and $0.03 \mathrm{~N}$ ). Here, semiconductor strain gauges can be used to increase sensitivity, or the mechanical structures can be optimised to produce higher strains for the applied load in the horizontal directions. The ideal mechanical structure would thus have a high strain per applied load, but such a design is compromised by the need to be sufficiently rigid to not disturb the mouse during walking. While the design utilised to measure GRFs in ants [30] might be more susceptible to breakage, the other four sensor designs $[26,56,59,60]$ all appear to be suitable choices.

In summary, to measure 3D GRFs for individual paws during mouse gait, we recommend adapting one of the four structures outlined in $[26,56,59,60]$ using resistance strain gauges. The structure in the locust study [59] was used only with semiconductor strain gauges, and therefore sufficient sensitivity cannot be guaranteed when combined with metal strain gauges instead. On the other hand, the structures used in the rat, lizard, and chick studies $[26,56,60]$ were already constructed with metal strain gauges, and thus their sensitivity after adaptation is likely to be sufficient. For our upcoming study, which will measure GRFs in mice per paw before and after bone surgery, we have chosen to adapt the mechanical design of the locust study [59] and to use resistive strain gauges as a sensing technique. Nevertheless, no matter what design is chosen, the miniaturised needs to be tested extensively to ensure the quality of the measurement, particularly the effect of changing the dimensions of the plate on the natural frequency and the sensitivity, as well as the position of the sensors on the uniformity of the measurement.

Funding: This project was financially supported by a research grant from ETH Zürich, ETH-18 16-2. Institutional Review Board Statement: Not applicable.

Informed Consent Statement: Not applicable.

Data Availability Statement: Not applicable.

Acknowledgments: We acknowledge Colin Smith for his help and his insightful input.

Conflicts of Interest: There are no conflict of interest.

\section{References}

1. Baker, R. Gait analysis methods in rehabilitation. J. Neuroeng. Rehabil. 2006, 3, 4. [CrossRef]

2. Cronin, J.B.; Bressel, E.; Fkinn, L. Augmented Feedback Reduces Ground Reaction Forces in the Landing Phase of the Volleyball Spike Jump. J. Sport Rehabil. 2008, 17, 148-159. [CrossRef] [PubMed] 
3. Hanley, B.; Bissas, A. Ground reaction forces of Olympic and World Championship race walkers. Eur. J. Sport Sci. 2014, 16, 1-7. [CrossRef] [PubMed]

4. Chen, P.-H.; Wang, R.-L.; Liou, D.-J.; Shaw, J.-S. Gait Disorders in Parkinson's Disease: Assessment and Management. Int. J. Gerontol. 2013, 7, 189-193. [CrossRef]

5. Muniz, A.M.S.; Liu, H.; Lyons, K.E.; Pahwa, R.; Liu, W.; Nadal, J. Quantitative Evaluation of the Effects of Subthalamic Stimulation on Gait in Parkinson's Disease Patients Using Principal Component Analysis. Int. J. Neurosci. 2010, 120, 609-616. [CrossRef] [PubMed]

6. Mora-Macías, J.; Reina-Romo, E.; Morgaz, J.; Dominguez, J. In Vivo Gait Analysis During Bone Transport. Ann. Biomed. Eng. 2015, 43, 2090-2100. [CrossRef]

7. Gaudreault, N.; Gravel, D.; Nadeau, S.; Houde, S.; Gagnon, D. Gait patterns comparison of children with Duchenne muscular dystrophy to those of control subjects considering the effect of gait velocity. Gait Posture 2010, 32, 342-347. [CrossRef]

8. Kloefkorn, H.E.; Jacobs, B.Y.; Loye, A.M.; Allen, K.D. Spatiotemporal gait compensations following medial collateral ligament and medial meniscus injury in the rat: Correlating gait patterns to joint damage. Arthritis Res. 2015, 17, 287. [CrossRef]

9. Yusof, M.I.; Shaharudin, S.; Sivalingarajah, P. Does Vertical Ground Reaction Force of the Hip, Knee, and Ankle Joints Change in Patients with Adolescent Idiopathic Scoliosis after Spinal Fusion? Asian Spine J. 2018, 12, 349-355. [CrossRef]

10. Nejad, Z.I.; Khalili, K.; Nasab, S.H.H.; Schütz, P.; Damm, P.; Trepczynski, A.; Taylor, W.R.; Smith, C.R. The Capacity of Generic Musculoskeletal Simulations to Predict Knee Joint Loading Using the CAMS-Knee Datasets. Ann. Biomed. Eng. 2020, 48, 1430-1440. [CrossRef]

11. Tang, W.; Lovering, R.M.; Roche, J.A.; Bloch, R.J.; Neerchal, N.K.; Tasch, U. Gait analysis of locomotory impairment in rats before and after neuromuscular injury. J. Neurosci. Methods 2009, 181, 249-256. [CrossRef]

12. Brand, R.V.D.; Heutschi, J.; Barraud, Q.; DiGiovanna, J.; Bartholdi, K.; Huerlimann, M.; Friedli, L.; Vollenweider, I.; Moraud, E.M.; Duis, S.; et al. Restoring Voluntary Control of Locomotion after Paralyzing Spinal Cord Injury. Science 2012, 336, 1182-1185. [CrossRef]

13. Scheuren, A.C.; Vallaster, P.; Kuhn, G.A.; Paul, G.R.; Malhotra, A.; Kameo, Y.; Müller, R. Mechano-Regulation of Trabecular Bone Adaptation Is Controlled by the Local in vivo Environment and Loga-rithmically Dependent on Loading Frequency. Front. Bioeng. Biotechnol. 2020, 8, 566346. [CrossRef]

14. Paul, G.R.; Malhotra, A.; Müller, R. Mechanical Stimuli in the Local In Vivo Environment in Bone: Computational Approaches Linking Organ-Scale Loads to Cellular Signals. Curr. Osteoporos. Rep. 2018, 16, 395-403. [CrossRef] [PubMed]

15. Liedtke, C.; Fokkenrood, S.A.; Menger, J.T.; Van Der Kooij, H.; Veltink, P.H. Evaluation of instrumented shoes for ambulatory assessment of ground reaction forces. Gait Posture 2007, 26, 39-47. [CrossRef]

16. Liu, T.; Inoue, Y.; Shibata, K.; Shiojima, K. Three-dimensional lower limb kinematic and kinetic analysis based on a wireless sensor system. In Proceedings of the 2011 IEEE International Conference on Robotics and Automation, Shanghai, China, 9-13 May 2011; pp. 842-847.

17. Shahabpoor, E.; Pavic, A. Measurement of Walking Ground Reactions in Real-Life Environments: A Systematic Review of Tech-niques and Technologies. Sensors 2017, 17, 2085. [CrossRef]

18. Robin, D.; Chateau, H.; Falala, S.; Valette, J.; Pourcelot, P.; Ravary, B.; Denoix, J.-M.; Crevier-Denoix, N. Ground reaction forces in the horse at the walk, trot and gallop measured with an instrumented shoe. Comput. Methods Biomech. Biomed. Eng. 2008, 11, 195-196. [CrossRef]

19. Jay, G.D.; Elsaid, K.A.; Kelly, K.A.; Anderson, S.C.; Zhang, L.; Teeple, E.; Waller, K.A.; Fleming, B.C. Prevention of cartilage degeneration and gait asymmetry by lubricin tribosupplementation in the rat following anterior cruciate ligament transection. Arthritis Rheum. 2011, 64, 1162-1171. [CrossRef]

20. Hsu, J.E.; Reuther, K.E.; Sarver, J.J.; Lee, C.S.; Thomas, S.J.; Glaser, D.L.; Soslowsky, L.J. Restoration of anterior-posterior rotator cuff force balance improves shoulder function in a rat model of chronic massive tears. J. Orthop. Res. 2011, 29, $1028-1033$. [CrossRef] [PubMed]

21. Campolo, D.; Cavallo, G.; Keller, F.; Accoto, D.; Dario, P.; Guglielmelli, E. Design and development of a miniaturized 2-axis force sensor for tremor analysis during locomotion in small-sized animal models. IEEE 2005, 5, 5054-5057.

22. Bogert, A.J.V.D. Analysis and simulation of mechanical loads on the human musculoskeletal system: A methodological overview. Exerc. Sport Sci. Rev. 1994, 22, 23-51. [CrossRef]

23. Wong, J.; Bennett, W.; Ferguson, M.W.; McGrouther, D.A. Microscopic and histological examination of the mouse hindpaw digit and flexor tendon arrangement with 3D recon-struction. J. Anat. 2006, 209, 533-545. [CrossRef] [PubMed]

24. Zumwalt, A.C.; Hamrick, M.; Schmitt, D. Force plate for measuring the ground reaction forces in small animal locomotion. J. Biomech. 2006, 39, 2877-2881. [CrossRef]

25. Tasch, U.; Moubarak, P.; Tang, W.; Zhu, L.; Lovering, R.M.; Roche, J.; Bloch, R.J. An Instrument That Simultaneously Measures Spatiotemporal Gait Parameters and Ground Reaction Forces of Loco-moting Rats. In Proceedings of the 9th Biennial Conference on Engineering Systems Design and Analysis, Haifa, Israel, 7-9 July 2008; Volume 2, pp. 45-49.

26. Biewener, A.; Full, R.J. Force platform and kinematic analysis. Biomech. Struct. Syst. A Pract. Approach 1992, 45-73.

27. Muir, G.D.; Whishaw, I.Q. ; Whishaw, I.Q. Ground reaction forces in locomoting hemi-parkinsonian rats: A definitive test for impairments and com-pensations. Exp. Brain Res. 1999, 126, 307-314. [CrossRef] 
28. Cavallo, G.; Campolo, D.; Keller, F.; Guglielmelli, E. A Modular Platform for In-plane Ground Reaction Forces Detection in a Mouse Model: Design, Development and Verification. Adv. Robot. 2008, 22, 141-157. [CrossRef]

29. Costello, K.E.; Guilak, F.; Setton, L.A.; Griffin, T.M. Locomotor activity and gait in aged mice deficient for type IX collagen. J. Appl. Physiol. 2010, 109, 211-218. [CrossRef]

30. Reinhardt, L.; Blickhan, R. Ultra-miniature force plate for measuring triaxial forces in the micronewton range. J. Exp. Biol. 2014, 217, 704-710. [CrossRef]

31. Cobos, E.J.; Ghasemlou, N.; Araldi, D.; Segal, D.; Duong, K.; Woolf, C.J. Inflammation-induced decrease in voluntary wheel running in mice: A nonreflexive test for evaluating inflammatory pain and analgesia. Pain 2012, 153, 876-884. [CrossRef]

32. Coutinho, A.E.; Fediuc, S.; Campbell, J.E.; Riddell, M.C. Metabolic effects of voluntary wheel running in young and old Syrian golden hamsters. Physiol. Behav. 2006, 87, 360-367. [CrossRef] [PubMed]

33. Meijer, J.H.; Robbers, Y. Wheel running in the wild. Proc. R. Soc. B Biol. Sci. 2014, 281, 20140210. [CrossRef] [PubMed]

34. Roach, G.C.; Edke, M.; Griffin, T.M. A novel mouse running wheel that senses individual limb forces: Biomechanical validation and in vivo testing. J. Appl. Physiol. 2012, 113, 627-635. [CrossRef]

35. Smith, B.J.H.; Cullingford, L.; Usherwood, J.R. Identification of mouse gaits using a novel force-sensing exercise wheel. J. Appl. Physiol. 2015, 119, 704-718. [CrossRef]

36. Poulet, B. Non-invasive Loading Model of Murine Osteoarthritis. Curr. Rheumatol. Rep. 2016, 18, 40. [CrossRef] [PubMed]

37. Charles, J.P.; Cappellari, O.; Spence, A.J.; Wells, D.J.; Hutchinson, J.R. Muscle moment arms and sensitivity analysis of a mouse hindlimb musculoskeletal model. J. Anat. 2016, 229, 514-535. [CrossRef]

38. Charles, J.P.; Cappellari, O.; Spence, A.J.; Hutchinson, J.R.; Wells, D.J. Musculoskeletal Geometry, Muscle Architecture and Functional Specialisations of the Mouse Hindlimb. PLoS ONE 2016, 11, e0147669. [CrossRef] [PubMed]

39. Full, R.J.; Tu, M.S. Mechanics of six-legged runners. J. Exp. Biol. 1990, 148, 129-146.

40. Muir, G.D.; Katz, S.L.; Gosline, J.M.; Steeves, J.D. Asymmetric bipedal locomotion-an adaptive response to incomplete spinal injury in the chick. Exp. Brain Res. 1998, 122, 275-282. [CrossRef]

41. Heglund, N.C. A Simple Design for a Force-Plate to Measure Ground Reaction Forces. J. Exp. Biol. 1981, 93, 333-338.

42. Biewener, A.A.; Blickhan, R.; Perry, A.K.; Heglund, N.C.; Taylor, C.R. Muscle forces during locomotion in kangaroo rats: Force platform and tendon buckle measurements compared. J. Exp. Biol. 1988, 137, 191-205.

43. Biewener, A.A.; Blickhan, R. Kangaroo rat locomotion: Design for elastic energy storage or acceleration? J. Exp. Biol. 1988, 140, 243-255.

44. Takahashi, H.; Thanh-Vinh, N.; Jung, U.G.; Matsumoto, K.; Shimoyama, I. MEMS two-axis force plate array used to measure the ground reaction forces during the running motion of an ant. J. Micromech. Microeng. 2014, 24, 65014. [CrossRef]

45. Klarner, D.; Barnes, W.J.P. The Cuticular Stress Detector (Csd2) of the Crayfish Activity during Walking and Influences on Leg Coordination. J. Exp. Biol. 1986, 122, 161-175.

46. Campolo, D.; Cavallo, G.; Keller, F.; Accoto, D.; Dario, P.; Guglielmelli, E. A mechatronic system for in-plane ground-reaction-force measurement for tremor analysis in animal models. In Proceedings of the 2005 IEEE/RSJ International Conference on Intelligent Robots and Systems, Edmonton, AB, Canada, 2-6 August 2005; Volume 1-4, pp. 2505-2510.

47. Full, R.; Yamauchi, A.; Jindrich, D. Maximum single leg force production: Cockroaches righting on photoelastic gelatin. J. Exp. Biol. 1995, 198, 2441-2452. [PubMed]

48. Jindrich, D.L.; Full, R.J. Many-legged maneuverability: Dynamics of turning in hexapods. J. Exp. Biol. 1999, $202,1603-1623$. [PubMed]

49. Endlein, T.; Federle, W. On Heels and Toes: How Ants Climb with Adhesive Pads and Tarsal Friction Hair Arrays. PLoS ONE 2015, 10, e0141269. [CrossRef] [PubMed]

50. Full, R.J.; Tu, M.S. Mechanics of a rapid running insect: Two-, four- and six-legged locomotion. J. Exp. Biol. 1991, 156, $215-231$.

51. Full, R.J.; Blickhan, R.; Ting, L.H. Leg design in hexapedal runners. J. Exp. Biol. 1991, 158, 369-390.

52. Cavallo, G.; Campolo, D.; Guglielmelli, E.; Vollaro, S.; Keller, F. Mechatronics and Phenomics: A case-study on tremor detection during locomotion in small-sized animals. In Proceedings of the the First IEEE/RAS-EMBS International Conference on Biomedical Robotics and Biomechatronics, BioRob, Pisa, Italy, 20-22 February 2006; Volume 1-3, p. 376.

53. Provini, P.; Tobalske, B.W.; Crandell, K.E.; Abourachid, A. Transition from leg to wing forces during take-off in birds. J. Exp. Biol. 2012, 215, 4115-4124. [CrossRef]

54. Nauwelaerts, S.; Aerts, P. Take-off and landing forces in jumping frogs. J. Exp. Biol. 2006, 209, 66-77. [CrossRef]

55. Muir, G.D.; Whishaw, I.Q. Complete locomotor recovery following corticospinal tract lesions: Measurement of ground reaction forces during overground locomotion in rats. Behav. Brain Res. 1999, 103, 45-53. [CrossRef]

56. Muir, G.D.; Gosline, J.M.; Steeves, J.D. Ontogeny of bipedal locomotion: Walking and running in the chick. J. Physiol. 1996, 493, 589-601. [CrossRef] [PubMed]

57. Chen, J.J.; Peattie, A.M.; Autumn, K.; Full, R.J. Differential leg function in a sprawled-posture quadrupedal trotter. J. Exp. Biol. 2006, 209, 249-259. [CrossRef]

58. Riskin, D.K.; Bertram, J.E.A.; Hermanson, J.W. Testing the hindlimb-strength hypothesis: Non-aerial locomotion by Chiroptera is not constrained by the dimensions of the femur or tibia. J. Exp. Biol. 2005, 208, 1309-1319. [CrossRef]

59. Katz, S.L. and J.M. Gosline, Ontogenic Scaling of Jump Performance in the African Desert Locust (Schistocerca-Gregaria). J. Exp. Biol. 1993, 177, 81-111. 
60. Dai, Z.; Wang, Z.; Ji, A. Dynamics of gecko locomotion: A force-measuring array to measure 3D reaction forces. J. Exp. Biol. 2011, 214, 703-708. [CrossRef]

61. Endlein, T.; Ji, A.; Yuan, S.; Hill, I.; Wang, H.; Barnes, W.J.P.; Dai, Z.; Sitti, M. The use of clamping grips and friction pads by tree frogs for climbing curved surfaces. Proc. R. Soc. B Boil. Sci. 2017, 284, 20162867. [CrossRef] [PubMed]

62. Ji, A.; Yuan, S.; Endlein, T.; Hill, I.D.C.; Wang, W.; Wang, H.; Jiang, N.; Zhao, Z.; Barnes, W.J.P.; Dai, Z.; et al. A force-measuring and behaviour-recording system consisting of 24 individual 3D force plates for the study of single limb forces in climbing animals on a quasi-cylindrical tower. Bioinspiration Biomim. 2019, 14, 046004. [CrossRef]

63. Wang, Z.; Ji, A.; Endlein, T.; Samuel, D.; Yao, N.; Wang, Z.; Dai, Z. The role of fore- and hindlimbs during jumping in the Dybowski's frog (Rana dybowskii). J. Exp. Zool. Part A Ecol. Genet. Physiol. 2014, 321, 324-333. [CrossRef]

64. Wang, Z.; Gorb, S.N.; Dai, Z. Control strategies of gecko's toe in response to reduced gravity. Appl. Sci. 2020, 10, 2257. [CrossRef]

65. Reinhardt, L.; Blickhan, R. Level locomotion in wood ants: Evidence for grounded running. J. Exp. Biol. 2014, 217, 2358-2370. [CrossRef]

66. Dallmann, C.J.; Hoinville, T.; Dürr, V.; Schmitz, J. A load-based mechanism for inter-leg coordination in insects. Proc. R. Soc. B Boil. Sci. 2017, 284, 20171755. [CrossRef]

67. Dallmann, C.J.; Dürr, V.; Schmitz, J. Motor control of an insect leg during level and incline walking. J. Exp. Biol. 2019, 222, jeb188748. [CrossRef]

68. McElroy, E.J.; Wilson, R.; Biknevicius, A.R.; Reilly, S.M. A comparative study of single-leg ground reaction forces in running lizards. J. Exp. Biol. 2013, 217, 735-742. [CrossRef]

69. McElroy, E.J.; Reilly, S.M. The relationship between limb morphology, kinematics, and force during running: The evolution of loco-motor dynamics in lizards. Biol. J. Linn. Soc. 2009, 97, 634-651. [CrossRef]

70. Clemente, C.J.; Bishop, P.J.; Newman, N.; Hocknull, S.A. Steady bipedal locomotion with a forward situated whole-body centre of mass: The potential importance of tempo-rally asymmetric ground reaction forces. J. Zool. 2018, 304, 193-201. [CrossRef]

71. Kanagal, S.G.; Muir, G.D. Bilateral dorsal funicular lesions alter sensorimotor behaviour in rats. Exp. Neurol. 2007, 205, 513-524. [CrossRef] [PubMed]

72. Bennett, S.W.; Lanovaz, J.L.; Muir, G.D. The biomechanics of locomotor compensation after peripheral nerve lesion in the rat. Behav. Brain Res. 2012, 229, 391-400. [CrossRef]

73. Webb, A.A.; Muir, G.D. Compensatory Locomotor Adjustments of Rats with Cervical or Thoracic Spinal Cord Hemisections. J. Neurotrauma 2002, 19, 239-256. [CrossRef]

74. Webb, A.A.; Muir, G.D. Course of motor recovery following ventrolateral spinal cord injury in the rat. Behav. Brain Res. 2004, 155, 55-65. [CrossRef] [PubMed]

75. Kanagal, S.; Muir, G. The differential effects of cervical and thoracic dorsal funiculus lesions in rats. Behav. Brain Res. 2008, 187, 379-386. [CrossRef]

76. Muir, G.D.; Webb, A.A.; Kanagal, S.; Taylor, L. Dorsolateral cervical spinal injury differentially affects forelimb and hindlimb action in rats. Eur. J. Neurosci. 2007, 25, 1501-1510. [CrossRef]

77. Webb, A.A.; Gowribai, K.; Muir, G.D. Fischer (F-344) rats have different morphology, sensorimotor and locomotor abilities com-pared to Lewis, Long-Evans, Sprague-Dawley and Wistar rats. Behav. Brain Res. 2003, 144, 143-156. [CrossRef]

78. Wehner, T.; Wolfram, U.; Henzler, T.; Niemeyer, F.; Claes, L.; Simon, U. Internal forces and moments in the femur of the rat during gait. J. Biomech. 2010, 43, 2473-2479. [CrossRef] [PubMed]

79. Muir, G.D.; Whishaw, I.Q. Red nucleus lesions impair overground locomotion in rats: A kinetic analysis. Eur. J. Neurosci. 2000, 12, 1113-1122. [CrossRef] [PubMed]

80. Kanagal, S.G.; Muir, G.D. Task-dependent compensation after pyramidal tract and dorsolateral spinal lesions in rats. Exp. Neurol. 2009, 216, 193-206. [CrossRef] [PubMed]

81. Webb, A.A.; Muir, G.D. Unilateral dorsal column and rubrospinal tract injuries affect overground locomotion in the unrestrained rat. Eur. J. Neurosci. 2003, 18, 412-422. [CrossRef]

82. Riskin, D.K.; Parsons, S.; Schutt, W.A.; Carter, G.G.; Hermanson, J.W. Terrestrial locomotion of the New Zealand short-tailed bat Mystacina tuberculata and the common vampire bat Des-modus rotundus. J. Exp. Biol. 2006, 209, 1725-1736. [CrossRef] [PubMed]

83. Endlein, T.; Ji, A.; Samuel, D.; Yao, N.; Wang, Z.; Barnes, W.J.P.; Federle, W.; Kappl, M.; Dai, Z. Sticking like sticky tape: Tree frogs use friction forces to enhance attachment on overhanging surfaces. J. R. Soc. Interface 2013, 10, 20120838. [CrossRef]

84. Wang, Z.; Dai, Z.; Ji, A.; Ren, L.; Xing, Q.; Dai, L. Biomechanics of gecko locomotion: The patterns of reaction forces on inverted, vertical and horizontal substrates. Bioinspir. Biomim. 2015, 10, 16019. [CrossRef]

85. Wang, Z.; Dai, Z.; Li, W.; Ji, A.; Wang, W. How do the substrate reaction forces acting on a gecko's limbs respond to inclines? Naturwissenschaften 2015, 102, 7-1259. [CrossRef]

86. Reinhardt, L.; Weihmann, T.; Blickhan, R. Dynamics and kinematics of ant locomotion: Do wood ants climb on level surfaces? J. Exp. Biol. 2009, 212, 2426-2435. [CrossRef] [PubMed]

87. Wöhrl, T.; Reinhardt, L.; Blickhan, R. Propulsion in hexapod locomotion: How do desert ants traverse slopes? J. Exp. Biol. 2017, 220, 1618-1625. [CrossRef]

88. Katz, S.L.; Gosline, J.M. Scaling Modulus as a Degree-of-Freedom in the Design of Locust Legs. J. Exp. Biol. 1994, 187, $207-223$. [PubMed] 
89. Dallmann, C.J.; Dürr, V.; Schmitz, J. Joint torques in a freely walking insect reveal distinct functions of leg joints in propulsion and posture control. Proc. R. Soc. B Boil. Sci. 2016, 283, 20151708. [CrossRef]

90. Lévy, J.; Cruse, H. Controlling a system with redundant degrees of freedom. I. Torque distribution in still standing stick insects. J. Comp. Physiol. A 2008, 194, 719-733. [CrossRef] [PubMed]

91. Bartling, C.; Schmitz, J. Reaction to disturbances of a walking leg during stance. J. Exp. Biol. 2000, 203, 1211-1223.

92. Bartsch, M.S.; Federle, W.; Full, R.J.; Kenny, T.W. A Multiaxis Force Sensor for the Study of Insect Biomechanics. J. Microelectromech. Syst. 2007, 16, 709-718. [CrossRef]

93. Fowler, S.; Birkestrand, B.; Chen, R.; Moss, S.; Vorontsova, E.; Wang, G.; Zarcone, T. A force-plate actometer for quantitating rodent behaviors: Illustrative data on locomotion, rotation, spatial patterning, stereotypies, and tremor. J. Neurosci. Methods 2001, 107, 107-124. [CrossRef]

94. Fowler, S.C.; Miller, B.R.; Gaither, T.W.; Johnson, M.A.; Rebec, G.V. Force-plate quantification of progressive behavioral deficits in the R6/2 mouse model of Huntington's disease. Behav. Brain Res. 2009, 202, 130-137. [CrossRef]

95. Fowler, S.C.; Muma, N.A. Use of a force-sensing automated open field apparatus in a longitudinal study of multiple behavioral defi-cits in CAG140 Huntington's disease model mice. Behav. Brain Res. 2015, 294, 7-16. [CrossRef]

96. Dai, Y.; Dudek, N.L.; Li, Q.; Fowler, S.C.; Muma, N.A. Striatal Expression of a Calmodulin Fragment Improved Motor Function, Weight Loss, and Neuropathology in the R6/2 Mouse Model of Huntington's Disease. J. Neurosci. 2009, 29, 11550-11559. [CrossRef]

97. Handley, D.; Ross, J.; Carr, G. A force plate system for measuring low-magnitude reaction forces in small laboratory animals. Physiol. Behav. 1998, 64, 661-669. [CrossRef]

98. Welch, J.M.; Wade, J.A.; Hillberry, B.M.; Weaver, C.M. Force platform for rats measures fore and hind forces concurrently. J. Biomech. 2009, 42, 2734-2738. [CrossRef]

99. Welch, J.M.; Weaver, C.M.; Turner, C.H. Adaptations to free-fall impact are different in the shafts and bone ends of rat forelimbs. J. Appl. Physiol. 2004, 97, 1859-1865. [CrossRef]

100. Clarke, K.; Still, J. Development and consistency of gait in the mouse. Physiol. Behav. 2001, 73, 159-164. [CrossRef]

101. Clarke, K.A.; Still, J. Gait Analysis in the Mouse. Physiol. Behav. 1999, 66, 723-729. [CrossRef]

102. Clarke, K.A.; Heitmeyer, S.A.; Smith, A.G.; Taiwo, Y.O. Gait analysis in a rat model of osteoarthrosis. Physiol. Behav. 1997, 62, 951-954. [CrossRef]

103. Clarke, K. Differential fore- and hindpaw force transmission in the walking rat. Physiol. Behav. 1995, 58, 415-419. [CrossRef]

104. Clarke, K.A.; Smart, L.; Still, J. Ground reaction force and spatiotemporal measurements of the gait of the mouse. Behav. Res. Methodsinstrumentscomput. 2001, 33, 422-426. [CrossRef]

105. Manske, S.L.; Boyd, S.K.; Zernicke, R.F. Vertical ground reaction forces diminish in mice after botulinum toxin injection. J. Biomech. 2011, 44, 637-643. [CrossRef]

106. Miklyaeva, E.I.; Woodward, N.C.; Nikiforov, E.G.; Tompkins, G.J.; Klassen, F.; Ioffe, M.E.; Whishaw, I.Q. The ground reaction forces of postural adjustments during skilled reaching in unilateral dopamine-depleted hem-iparkinson rats. Behav. Brain Res. 1997, 88, 143-152. [CrossRef]

107. Rantalainen, T.; Silvennoinen, M.; Kainulainen, H.; Sievänen, H. Vertical ground reaction force measurements and video measurements provide comparable estimates of distance moved by mice during artificial light and dark periods. J. Neurosci. Methods 2011, 197, 104-108. [CrossRef]

108. Busshardt, P.; Gorb, S.N. Ground reaction forces in vertically ascending beetles and corresponding activity of the claw retractor muscle on smooth and rough substrates. J. Comp. Physiol. A Neuroethol. Sens. Neural. Behav. Physiol. 2014, 200, 385-398. [CrossRef]

109. Lin, H.T.; Trimmer, B.A. The substrate as a skeleton: Ground reaction forces from a soft-bodied legged animal. J. Exp. Biol. 2010, 213, 1133-1142. [CrossRef]

110. Vaughan, S.C.; Lin, H.-T.; Trimmer, B.A. Caterpillar Climbing: Robust, Tension-Based Omni-Directional Locomotion. J. Insect Sci. 2018, 18, 13. [CrossRef] [PubMed]

111. Hochman, S.; Gozal, E.A.; Hayes, H.B.; Anderson, J.T.; DeWeerth, S.P.; Chang, Y.H. Enabling techniques for in vitro studies on mammalian spinal locomotor mechanisms. Front Biosci. 2012, 17, 2158-2180. [CrossRef] [PubMed]

112. Ju, Y.-I.; Sone, T.; Ohnaru, K.; Tanaka, K.; Yamaguchi, H.; Fukunaga, M. Effects of Different Types of Jump Impact on Trabecular Bone Mass and Microarchitecture in Growing Rats. PLoS ONE 2014, 9, e107953. [CrossRef]

113. Wu, P.T.; Hsu, C.H.; Su, F.C.; Jou, I.M.; Chen, S.Y.; Wu, C.L.; Kuo, L.C. Dynamic weight bearing analysis is effective for evaluation of tendinopathy using a customized corridor with mul-ti-directional force sensors in a rat model. Sci. Rep. 2017, 7, 1-10.

114. Howard, C.S.; Blakeney, D.C.; Medige, J.; Moy, O.J.; Peimer, C.A. Functional assessment in the rat by ground reaction forces. J. Biomech. 2000, 33, 751-757. [CrossRef]

115. Diogo, C.C.; Da Costa, L.M.; Pereira, J.E.; Filipe, V.; Couto, P.A.; Geuna, S.; Armada-Da-Silva, P.A.; Maurício, A.C.; Varejão, A.S. Kinematic and kinetic gait analysis to evaluate functional recovery in thoracic spinal cord injured rats. Neurosci. Biobehav. Rev. 2019, 98, 18-28. [CrossRef]

116. Tang, W.; McDowell, K.; Limsam, M.; Neerchal, N.K.; Yarowsky, P.; Tasch, U. Locomotion analysis of Sprague-Dawley rats before and after injecting 6-OHDA. Behav. Brain Res. 2010, 210, 131-133. [CrossRef] [PubMed]

117. Tang, W.; Tasch, U.; Neerchal, N.K.; Zhu, L.; Yarowsky, P. Measuring early pre-symptomatic changes in locomotion of SOD1-G93A rats-A rodent model of amyotrophic lateral sclerosis. J. Neurosci. Methods 2009, 176, 254-262. [CrossRef] [PubMed] 
118. Giszter, S.F.; Davies, M.R.; Graziani, V. Motor Strategies Used by Rats Spinalized at Birth to Maintain Stance in Response to Imposed Perturbations. J. Neurophysiol. 2007, 97, 2663-2675. [CrossRef] [PubMed]

119. Giszter, S.F.; Davies, M.R.; Graziani, V. Coordination strategies for limb forces during weight-bearing locomotion in normal rats, and in rats spinalized as neonates. Exp. Brain Res. 2008, 190, 53-69. [CrossRef]

120. Nessler, J.A.; Moustafa-Bayoumi, M.; Soto, D.; Duhon, J.; Schmitt, R. Assessment of Hindlimb Locomotor Strength in Spinal Cord Transected Rats through Animal-Robot Contact Force. J. Biomech. Eng. 2011, 133, 121007. [CrossRef] [PubMed]

121. Pardes, A.; Freedman, B.; Soslowsky, L. Ground reaction forces are more sensitive gait measures than temporal parameters in rodents following rotator cuff injury. J. Biomech. 2016, 49, 376-381. [CrossRef]

122. Silva, N.; Sousa, J.J.; Peres, E.; Sousa, A.; Ruiz-Armenteros, A.M.; Varejão, A.; Morais, R. A cost-effective instrumented walkway for measuring ground reaction forces in rats to assess gait pattern. Measurement 2017, 103, 241-249. [CrossRef]

123. Song, H.; Polk, J.D.; Kersh, M.E. Rat bone properties and their relationship to gait during growth. J. Exp. Biol. 2019, 222, jeb203554. [CrossRef] [PubMed]

124. Sarver, J.J.; Dishowitz, M.I.; Kim, S.-Y.; Soslowsky, L.J. Transient decreases in forelimb gait and ground reaction forces following rotator cuff injury and repair in a rat model. J. Biomech. 2010, 43, 778-782. [CrossRef]

125. Andrada, E.; Nyakatura, J.A.; Bergmann, F.; Blickhan, R. Adjustments of global and local hindlimb properties during terrestrial locomotion of the common quail (Coturnix coturnix). J. Exp. Biol. 2013, 216, 3906-3916. [CrossRef]

126. Andrada, E.; Rode, C.; Blickhan, R. Grounded running in quails: Simulations indicate benefits of observed fixed aperture angle between legs before touch-down. J. Theor. Biol. 2013, 335, 97-107. [CrossRef]

127. Andrada, E.; Rode, C.; Sutedja, Y.; Nyakatura, J.A.; Blickhan, R. Trunk orientation causes asymmetries in leg function in small bird terrestrial locomotion. Proc. R. Soc. B Biol. Sci. 2014, 281, 20141405. [CrossRef]

128. Jagnandan, K.; Russell, A.P.; Higham, T.E. Tail autotomy and subsequent regeneration alter the mechanics of locomotion in lizards. J. Exp. Biol. 2014, 217, 3891-3897. [CrossRef]

129. Rode, C.; Sutedja, Y.; Kilbourne, B.M.; Blickhan, R.; Andrada, E. Minimizing the cost of locomotion with inclined trunk predicts crouched leg kinematics of small birds at realistic levels of elastic recoil. J. Exp. Biol. 2016, 219, 485-490. [CrossRef]

130. Porro, L.B.; Collings, A.J.; Eberhard, E.A.; Chadwick, K.P.; Richards, C.T. Inverse dynamic modelling of jumping in the red-legged running frog, Kassina maculata. J. Exp. Biol. 2017, 220, 1882-1893. [CrossRef]

131. Reilly, S.M.; Montuelle, S.J.; Schmidt, A.; Krause, C.; Naylor, E.; Essner, R.L. Functional evolution of jumping in frogs: Interspecific differences in take-off and landing. J. Morphol. 2016, 277, 379-393. [CrossRef]

132. Main, R.P.; Biewener, A.A. Skeletal strain patterns and growth in the emu hindlimb during ontogeny. J. Exp. Biol. 2007, 210, 2676-2690. [CrossRef]

133. Hancock, J.A.; Stevens, N.J.; Biknevicius, A.R. Elegant-crested Tinamous Eudromia elegans do not synchronize head and leg movements during head-bobbing. Ibis 2014, 156, 198-208. [CrossRef]

134. Body Motion Analysis. In Sensors in Medicine and Health Care; Wiley-VCH: Weinheim, Germany; pp. $243-281$.

135. Hancock, J.A.; Stevens, N.J.; Biknevicius, A.R. Whole-body mechanics and kinematics of terrestrial locomotion in the Ele-gantcrested Tinamou Eudromia elegans. Ibis 2007, 149, 605-614. [CrossRef]

136. Provini, P.; Tobalske, B.W.; Crandell, K.E.; Abourachid, A. Transition from wing to leg forces during landing in birds. J. Exp. Biol. 2014, 217, 2659-2666. [CrossRef]

137. Johnson, W.L.; Jindrich, D.L.; Roy, R.R.; Edgerton, V.R. Quantitative metrics of spinal cord injury recovery in the rat using motion capture, electromyography and ground reaction force measurement. J. Neurosci. Methods 2012, 206, 65-72. [CrossRef] [PubMed]

138. Kemp, S.W.; Webb, A.A.; Dhaliwal, S.; Syed, S.; Walsh, S.K.; Midha, R. Dose and duration of nerve growth factor (NGF) administration determine the extent of behavioral recovery following peripheral nerve injury in the rat. Exp. Neurol. 2011, 229, 460-470. [CrossRef]

139. Bain, S.D.; Huber, P.; Ausk, B.J.; Kwon, R.Y.; Gardiner, E.M.; Srinivasan, S.; Gross, T.S. Neuromuscular dysfunction, independent of gait dysfunction, modulates trabecular bone homeostasis in mice. J. Musculoskelet. Neuronal Interact. 2019, 19, 79-93. [PubMed]

140. Rapp, A.E.; Kroner, J.; Baur, S.; Schmid, F.; Walmsley, A.; Mottl, H.; Ignatius, A. Analgesia via blockade of NGF/TrkA signaling does not influence fracture healing in mice. J. Orthop. Res. 2015, 33, 1235-1241. [CrossRef]

141. Röntgen, V.; Blakytny, R.; Matthys, R.; Landauer, M.; Wehner, T.; Göckelmann, M.; Jermendy, P.; Amling, M.; Schinke, T.; Claes, L.; et al. Fracture healing in mice under controlled rigid and flexible conditions using an adjustable external fixator. J. Orthop. Res. 2010, 28, 1456-1462. [CrossRef]

142. Roemhildt, M.L.; Gardner-Morse, M.; Rowell, C.; Beynnon, B.D.; Badger, G.J. Gait alterations in rats following attachment of a device and application of altered knee loading. J. Biomech. 2010, 43, 3227-3231. [CrossRef]

143. Schmitt, D.; Zumwalt, A.C.; Hamrick, M.W. The relationship between bone mechanical properties and ground reaction forces in normal and hypermuscular mice. J. Exp. Zool. Part A Ecol. Genet. Physiol. 2010, 313, 339-351. [CrossRef]

144. Alant, J.D.D.V.; Kemp, S.W.P.; Khu, K.J.O.L.; Kumar, R.; Webb, A.A.; Midha, R. Traumatic Neuroma in Continuity Injury Model in Rodents. J. Neurotrauma 2012, 29, 1691-1703. [CrossRef]

145. Allen, K.D.; Mata, B.A.; Gabr, M.A.; Huebner, J.L.; Adams, S.B.; Kraus, V.B.; Schmitt, D.O.; Setton, L.A. Kinematic and dynamic gait compensations resulting from knee instability in a rat model of osteoarthritis. Arthritis Res. 2012, 14, R78. [CrossRef]

146. Webb, A.A.; Kerr, B.; Neville, T.; Ngan, S.; Assem, H. Kinematics and Ground Reaction Force Determination: A Demonstration Quantifying Locomotor Abilities of Young Adult, Middle-aged, and Geriatric Rats. J. Vis. Exp. 2011, 2011, e2138. [CrossRef] 
147. Kemp, S.W.P.; Alant, J.; Walsh, S.K.; Webb, A.A.; Midha, R. Behavioural and anatomical analysis of selective tibial nerve branch transfer to the deep peroneal nerve in the rat. Eur. J. Neurosci. 2010, 31, 1074-1090. [CrossRef]

148. Shimada, H.; Kanai, R.; Kondo, T.; Yoshino-Saito, K.; Uchida, A.; Nakamura, M.; Ogihara, N. Three-dimensional kinematic and kinetic analysis of quadrupedal walking in the common marmoset (Callithrix jac-chus). Neurosci. Res. 2017, 125, 11-20. [CrossRef]

149. Lammers, A.R. Mechanics of generating friction during locomotion on rough and smooth arboreal trackways. J. Exp. Biol. 2009, 212, 1163-1169. [CrossRef]

150. Lammers, A.R.; Gauntner, T. Mechanics of torque generation during quadrupedal arboreal locomotion. J. Biomech. 2008, 41, 2388-2395. [CrossRef]

151. Wan, C.; Cao, R.; Hao, Z. The Effect of Ground Type on the Jump Performance of Adults of the Locust Locusta migratoria manilen-sis: A Preliminary Study. Insects 2020, 11, 259. [CrossRef] 